\title{
Metastatic Head and Neck Squamous Cell Carcinoma
}

National Cancer Institute

\section{Source}

National Cancer Institute. Metastatic Head and Neck Squamous Cell Carcinoma. NCI

Thesaurus. Code C148153.

A head and neck squamous cell carcinoma which has spread from the original site of growth to another anatomic site. 